\title{
Development and evaluation of a monoclonal antibody inhibition enzyme linked immunosorbent assay to diagnose syphilis
}

\author{
O E IJSSELMUIDEN,* J TOP, $†$ E STOLZ,* R V W vaN EIJK $†$
}

From the *Department of Dermatovenereology, University Hospital Dijkzigt, Rotterdam; and the $\nmid$ Laboratory of Bacteriology, National Institute of Public Health and Environmental Protection, Bilthoven, The Netherlands

SUMMARY A highly specific inhibition enzyme linked immunosorbent assay (ELISA) using murine monoclonal antibodies to treponemes has been developed to diagnose syphilis. The monoclonal antibodies used in this study were reactive to antigens of both Treponema pallidum and Treponema pertenue and not to antigens of non-pathogenic treponemes. Inhibition of the binding of monoclonal antibody to the treponemal antigens was successful with serum antibodies of patients with syphilis in an inhibition ELISA using monoclonal antibodies raised against $T$ pallidum antigens with molecular weights of 42 and 47 kilodaltons. In contrast, the binding of monoclonal antibodies obtained by immunising mice with treponemal membrane protein $T m p B$, derived from recombinant DNA was not inhibited by serum antibodies from patients with syphilis. The sensitivity of the inhibition ELISA using monoclonal antibody against the 47 kilodalton $T$ pallidum antigen was $93 \%$ in 58 serum samples from patients with untreated syphilis. The sensitivity was $79 \%$ if the monoclonal antibody against the 42 kilodalton $T$ pallidum antigen was used. By a combination of the test results obtained in these two inhibition assays a sensitivity of $97 \%$ in the 58 serum samples from untreated patients and $64 \%$ in 64 from treated patients was obtained. The specificity of the inhibition ELISA performed with either monoclonal antibody was $100 \%$ in 500 serum samples from non-infected people. The specificity in 432 non-infected patients attending a sexually transmitted disease clinic was $98.8 \%$ for the monoclonal antibody against the 42 kilodalton antigen, $99.5 \%$ for the monoclonal antibody against the 47 kilodalton antigen, and $98.4 \%$ for the combined antibodies. The sensitivity and specificity of the inhibition ELISA using the combination of test results obtained by the application of the monoclonal antibodies against the 42 kilodalton treponemal membrane protein, TmpA, and against the 47 kilodalton $T$ pallidum antigen were comparable with those of the Treponema pallidum haemagglutination assay (TPHA) and the fluorescent treponemal antibody absorption (FTA-ABS) test for diagnosing early untreated disease. The inhibition ELISA offers the potential for additional confirmation of early untreated syphilis. Its use for confirming late untreated syphilis is still under investigation. The test is highly specific for pathogenic treponemes and does not need sorbens.

Most infectious diseases lead to an immune response that elicits antibodies against different antigenic determinants of the causative organism. The range of determinants to which antibodies are raised is large and includes pathogen specific epitopes as well as determinants that are common to (un)related bacteria. The immune response to common antigens in patients with syphilis leads to non-specific reactions in diagnostic tests using Treponema pallidum subsp pallidum

Address for reprints: Dr R V W van Eijk, Central Laboratory of the Netherlands Red Cross Blood Transfusion Service, PO Box 9190, 1006 AD Amsterdam, The Netherlands

Accepted for publication 14 March 1989
( $T$ pallidum) as antigen. In these serological tests a sorbens is therefore often used to remove serum antibodies that are not specific for $T$ pallidum.$^{1-3}$ The effectiveness of such a sorbens is not well defined, which stresses the need for serological tests using well defined specific antigens. Immunoassays using purified antigens $s^{4}$ or recombinant proteins ${ }^{56}$ and immunoblotting techniques ${ }^{7}$ have been proposed as serological tests for syphilis without the need for a sorbens.

The application of monoclonal antibodies (MoAbs) to detect treponemal antibody may provide a highly specific tool for diagnosing treponematoses. Such a 
test, which takes advantage of the high specificity of MoAbs, will probably show the high specificity required of a confirmatory test.

Studies of the reactivity of MoAbs raised against $T$ pallidum or its components have resulted in MoAbs that were specific for pathogenic treponemes and those that were reactive with non-pathogenic and pathogenic spirochaetes. ${ }^{8-14}$ Those studies also showed that the pathogen specific MoAbs could not yet distinguish between different pathogenic subspecies of treponemes, such as $T$ pallidum subsp pallidum, subsp pertenue, and subsp carateum. This agrees with the observation that $T$ pallidum subsp pallidum (which causes syphilis) and subsp pertenue (which causes yaws) showed only minor differences in their protein patterns in two dimensional gels, western blots, and in studies of their genetic relation. ${ }^{1516}$

Binding of pathogen specific MoAbs to $T$ pallidum antigens can be inhibited by the serum of patients suffering from syphilis, ${ }^{13}$ which indicates that a competitive inhibition assay using pathogen specific MoAbs may be suitable to diagnose syphilis. In this study eight monoclonal antibodies raised to three different $T$ pallidum antigens of molecular weights 47 , 42 , and 34 kilodalton were investigated for their suitability for use in an inhibition ELISA. We developed an inhibition ELISA using MoAbs directed to 42 and 47 kilodalton proteins and compared this assay for sensitivity and specificity with the $T$ pallidum haemagglutination assay (TPHA), fluorescent treponemal antibody absorption (FTA-ABS) test, and the Venereal Disease Research Laboratory (VDRL) test for diagnosing untreated and treated syphilis.

\section{Patients, materials, and methods}

\section{ANTIGENS}

$T$ pallidum subsp pallidum, $T$ pallidum subsp pertenue (T pertenue), and $T$ phagedenis, biotype Reiter, were used to evaluate the specificity of the different monoclonal antibodies used in this study. $T$ pallidum (Nichols strain) was cultured by serial passage in rabbit testes. Treponemes were extracted from the rabbit testicular tissue and subsequently purified by being urografin density centrifuged, as described previously. ${ }^{17} 18$ Preparations of $10^{10}$ treponemes $/ \mathrm{ml}$ in phosphate buffered saline (PBS) were stored at $-70^{\circ} \mathrm{C}$. $T$ pertenue, strain Gauthier, kindly provided by $\mathbf{P}$ Hindersson, Copenhagen, was essentially prepared in the same way as $T$ pallidum. $T$ phagedenis was cultured in Brewer's thioglycollate medium with $10 \%(\mathrm{v} / \mathrm{v})$ heat inactivated rabbit serum as described previously. ${ }^{19}$

Before being used in ELISA or immunoblotting experiments, the treponemes were suspended in TRIS buffer $(0.01 \mathrm{~mol} / 1 \mathrm{TRIS}$ hydrochloric acid, $\mathrm{pH} 7 \cdot 4$, and
$0.15 \mathrm{~mol} / 1$ sodium chloride) and submitted to ultrasonic treatment three times for 15 seconds each using a Branson sonifier at $20 \mathrm{kHz}, 50 \mathrm{~W}$. The sonicates were stored at $-20^{\circ} \mathrm{C}$ until used.

\section{SERUM SAMPLES}

Serum samples from 58 patients with untreated syphilis had been stored at $-20^{\circ} \mathrm{C}$. Fresh samples submitted for syphilis serology tests were obtained from 496 patients (with or without syphilis) attending the sexually transmitted disease (STD) clinic at the University Hospital in Rotterdam. Sixty four of the fresh samples submitted for syphilis serology tests, which were obtained from patients who had been treated for syphilis, were reactive in at least one treponemal test. Five hundred samples from noninfected people were obtained from blood donors attending the Rotterdam blood bank. The patients with syphilis were classified clinically and serologically as described previously. ${ }^{3}$ All samples were tested in the TPHA (Japan Lyophylization Company) and the FTA-ABS and VDRL tests. ${ }^{20}$

To investigate the possible cross reactivity of samples from patients with other spirochaetoses in the inhibition ELISA, six samples reactive in an immunofluorescence test to Borrelia burgdorferi ${ }^{21}$ and seven reactive in an ELISA to Leptospira, strain Wijnberg, serotype icterohaemorrhagiae, ${ }^{22}$ were also tested in the inhibition ELISA (courtesy of Dr W J Terpstra, WHO/FHO collaborating centre for serology and research on leptospirosis, Amsterdam).

\section{PREPARING AND CHARACTERISING}

MONOCLONAL ANTIBODIES (MoAbs)

Details of producing and selecting MoAbs have been described elsewhere." Hybridoma cultures of antibody to $T$ pallidum were selected by $T$ pallidum ELISA, as reported by Van Eijk et al. ${ }^{23}$ MoAbs C3E5, D6F7C6, and 1-14M1 were prepared from mice that had been immunised with $T$ pallidum and MoAbs 15 , $21,29,30$, and 34 were prepared from mice that had been injected with the 34 kilodalton recombinant DNA derived treponemal membrane protein TmpB. ${ }^{24}$

The MoAbs were purified by adding saturated ammonium sulphate solution to the ascites fluids to make a final saturation of $50 \%$, which was mixed for one hour at $4^{\circ} \mathrm{C}$ by slow rotation. The insoluble proteins were pelleted by being centrifuged for 10 minutes at $10000 \times \mathrm{g}$. The pellet was rinsed with $50 \%$ saturated ammonium sulphate and centrifuged again. The final pellet was dissolved in $10 \mathrm{mmol} / 1$ sodium phosphate buffer (disodium hydrogen and sodium dihydrogen phosphate and $0.01 \mathrm{mmol} / 1$ calcium chloride, $\mathrm{pH}$ 6.8) and dialysed overnight against the same buffer. Final purification was accomplished by 
high performance liquid chromatography using a hydroxylapatite column $(100 \times 7.8 \mathrm{~mm}$, LKB, Sweden). Up to $2.5 \mathrm{mg}$ monoclonal antibody dissolved in $2 \mathrm{ml}$ of a $10 \mathrm{mmol} / 1$ sodium phosphate buffer was loaded into the column. A 10 to $350 \mathrm{mmol} / \mathrm{l}$ sodium phosphate buffer gradient was run in 30 minutes at a flow rate of $1 \mathrm{ml} / \mathrm{minute}$. The fractions that contained protein, as estimated by absorption at $280 \mathrm{~nm}$, were collected and used for further study.

Monoclonal antibody was labelled with horseradish peroxidase according to the method of Nakane and Kawaoi. ${ }^{25}$ MoAbs were characterised with the FTA test, TPHA, and ELISA using $T$ pallidum and $T$ phagedenis, biotype Reiter, antigens. The titre of each undiluted MoAb in the $T$ pallidum ELISA was defined as the MoAb dilution that showed half the extinction of the undiluted MoAb solution.

The suitability of the MoAbs for possible use in the inhibition ELISA was studied by inhibiting the binding of the conjugated MoAb by its homologous unlabelled counterpart that had been bound to the immobilised antigen. Binding of conjugated MoAb was inhibited by the unlabelled homologous MoAb in all cases except for D6F7C6, which was therefore excluded from further experiments.

\section{SDS-PAGE AND WESTERN BLOTTING}

Sonicated $T$ pallidum, $T$ pertenue, and $T$ phagedenis were dissolved in 3\% sodium dodecyl sulphate (SDS) by being heated in a boiling water bath for three minutes under reducing conditions using 2\% 2-mercaptoethanol. Sodium dodecyl sulphate-polyacrylamide gel electrophoresis (SDS-PAGE) was performed using $13 \%$ slab gels $(17 \times 12 \mathrm{~cm})$ as described by Laemmli. $^{26}$ Immunoblotting was performed to identify the components of the pathogenic and nonpathogenic treponemes to which the monoclonal antibodies were directed. Electrophoretic transfer of proteins to nitrocellulose was performed with a transblot apparatus (Biorad, USA) using the method of Burnette. ${ }^{27}$ After the proteins had been transferred, the nitrocellulose was cut into separate strips. Each strip was soaked in PBS containing 0.05\% Tween 20 (polysorbate 20) (PBS-T) for 15 minutes and incubated for one hour with MoAb diluted 1:100 in PBS-T. After being rinsed in PBS-T for 10 minutes, the nitrocellulose strips were incubated for one hour with 1:1000 dilution of antibodies to mouse (RIVM, The Netherlands) or human (Nordic, The Netherlands) immunoglobulin labelled with horseradish peroxidase. The nitrocellulose strips were rinsed again, the substrate solution, which contained $0.6 \mathrm{mg} / \mathrm{ml}$ tetramethyl-benzidine, $2 \mathrm{mg} / \mathrm{ml}$ dioctylsodiumsulphosuccinate and $0.015 \%(\mathrm{v} / \mathrm{v})$ hydrogen peroxide in citrate/ phosphate buffer $(5 \mathrm{mmol} / \mathrm{ml}$ citric acid, $10 \mathrm{mmol} / 1$ disodium hydrogen phosphate, $\mathrm{pH} 5 \cdot 0$, and $25 \%$ (v/v) ethanol), was added, and they were incubated for 10 minutes.

\section{TITRATION OF MONOCLONAL ANTIBODIES IN} $T$ pallidum ELISA

The optimum dilution of each monoclonal antibody labelled with horseradish peroxidase was assessed by titration in the $T$ pallidum ELISA. For this purpose a microtitration plate precoated with $T$ pallidum ultrasonicate was incubated for one hour with labelled $\mathrm{MoAb}$ in increasing dilutions. Ten minutes after adding $0.1 \mathrm{ml}$ substrate solution $(0.1 \mathrm{mg} / \mathrm{ml}$ tetramethylbenzidine, $0.009 \%$ hydrogen peroxide, and $0.11 \mathrm{~mol} / 1$ sodium acetate, adjusted with citric acid to $\mathrm{pH} \mathrm{5.5),} \mathrm{the} \mathrm{reaction} \mathrm{was} \mathrm{stopped} \mathrm{by} \mathrm{adding} 3 \mathrm{~mol} / 1$ sulphuric acid. The extinctions were measured and plotted against the appropriate dilution of the labelled monoclonal antibody.

\section{INHIBITION ELISA}

Preliminary experiments had shown that maximum inhibition of monoclonal antibody binding to the antigens by serum antibodies was achieved by incubating a low dilution of the patient's serum before incubating the MoAb. The patient's serum diluted to the same extent had also to be added to the MoAb solution during its incubation. To incorporate these conditions, the inhibition ELISA was performed as follows: $0.1 \mathrm{ml}$ of $T$ pallidum sonicate $\left(2.7 \times 10^{7}\right.$ treponemes/ml PBS) was coated on to the wells of a microtitration plate ( 96 wells, Dynatech, Germany) by incubating the plates for one hour at $37^{\circ} \mathrm{C}$. The plate was rinsed for 30 seconds in a continuous low pressure flow of rinsing buffer (TS-buffer containing $\mathbf{0 . 0 5 \%}$ Tween 20). The patient's serum diluted 1:5, 1:50, and 1:100 in PBS-T was then added to the wells and incubated for one hour at $37^{\circ} \mathrm{C}$. The plates were rinsed with PBS-T and appropriately diluted test serum mixed with labelled MoAbs at the indicated working dilution was added to the wells and incubated for one hour at $37^{\circ} \mathrm{C}$. The plates were rinsed with PBS-T, and $0.1 \mathrm{ml}$ substrate solution was added to the wells and incubated. The reaction was stopped by adding $50 \mu \mathrm{l}$ of $3 \mathrm{~mol} / 1$ sulphuric acid. The extinction was measured with a multiscan (Titertek) at $450 \mathrm{~nm}$.

Appropriate control samples were included in each assay. The reactivity of each MoAb was checked by incubating without serum the appropriate MoAb labelled with horseradish peroxidase. The specificity of the reaction was checked using alpha-fetoprotein labelled with horseradish peroxidase as a control on each plate.

\section{Results}

SPECIFICITY OF MONOCLONAL ANTIBODIES To define the reactivity and specificity of MoAbs 
Table 1 Comparison of reactivity of monoclonal antibodies (MoAbs) in various tests using Treponema pallidum or $T$ phagedenis, biotype Reiter, antigens

\begin{tabular}{|c|c|c|c|c|c|}
\hline \multirow[b]{2}{*}{ Mo.4h } & \multirow{2}{*}{$\begin{array}{l}\text { Molecular weight } \\
\text { (kilodaltons) of } \\
\text { reactive antigen }\end{array}$} & \multicolumn{2}{|l|}{ ELISA titre } & \multirow{2}{*}{$\frac{F T A}{T \text { pallidum }}$} & \multirow{2}{*}{$\frac{T P H A \text { titre }}{T \text { pallidum }}$} \\
\hline & & $T$ pallidum & $T$ phagedenis & & \\
\hline $\begin{array}{l}15 \\
21 \\
29 \\
30 \\
34 \\
\text { C3E5 } \\
\text { D6F7C6 } \\
1-14 \mathrm{MI}\end{array}$ & $\begin{array}{l}34 \\
34 \\
34 \\
34 \\
34 \\
47 \\
47 \\
42\end{array}$ & $\begin{array}{l}1 / 25600 \\
1 / 800 \\
1 / 800 \\
1 / 1600 \\
1 / 1600 \\
1 / 12800 \\
1 / 12800 \\
1 / 51200\end{array}$ & $\begin{array}{l}\text { Negative } \\
\text { Negative } \\
\text { Negative } \\
\text { Negative } \\
\text { Negative } \\
\text { Negative } \\
\text { Negative } \\
\text { Negative }\end{array}$ & $\begin{array}{l}\text { Positive } \\
\text { Positive } \\
\text { Positive } \\
\text { Positive } \\
\text { Positive } \\
\text { Positive } \\
\text { Positive } \\
\text { Negative }\end{array}$ & $\begin{array}{l}1 / 128 \\
1 / 128 \\
1 / 128 \\
1 / 128 \\
1 / 128 \\
1 / 4 \\
1 / 128 \\
1 / 128\end{array}$ \\
\hline
\end{tabular}

ELISA $=$ enzyme linked immunosorbent assay. FTA $=$ fluorescent treponemal antibody test. TPHA $=T$ pallidum haemagglutination assay.

reactive to $T$ pallidum antigens, eight MoAbs directed to treponemal antigens of molecular weights 34,42 , and 47 kilodaltons were investigated in the ELISA, TPHA, FTA test, and western blot using $T$ pallidum, $T$ pertenue, and $T$ phagedenis antigens.

Table 1 shows the results of evaluating the eight monoclonal antibodies in the ELISA using $T$ pallidum or $T$ phagedenis antigens and in the FTA test and the TPHA using $T$ pallidum antigens. None of the MoAbs reacted with $T$ phagedenis antigens in the ELISA. All but one (1-14M1) reacted in the $T$ pallidum ELISA, FTA test, and TPHA. MoAb 1-14M1 reacted in the $T$ pallidum ELISA and TPHA, but not in the FTA test.

The reactivity of the MoAbs to $T$ pallidum, $T$ pertenue, and $T$ phagedenis was analysed by immunoblotting. Figure 1 shows the results of the immunoblotting with $T$ pallidum antigens. MoAbs C3E5 and

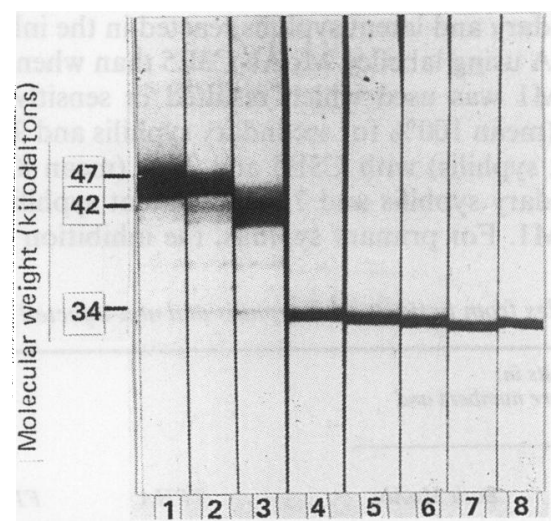

Fig 1 Monoclonal antibody (MoAb) reactivity to Treponema pallidum on western blots $\left(2.5 \times 10^{6}\right.$ treponemes per lane). Lanes 1 and 2 show reactivity of MoAbs C3E5 and D6F7C6, lane 3 shows reactivity of MoAb 1-14M1, lanes 4 to 8 show reactivity of $M o A b s$ 15, 21, 29, 30, and 34 raised to the 34 kilodalton treponemal membrane protein $B(T m p B)$ derived from recombinant $D N A$.
D6F7C6 reacted with both $T$ pallidum and $T$ pertenue antigens of 47 kilodaltons, and MoAb 1-14M1 with 42 kilodalton antigens. MoAbs 15, 21, 29, 30, and 34 reacted with 34 kilodalton antigens of $T$ pallidum and $T$ pertenue. None of the MoAbs was reactive to $T$ phagedenis antigens in immunoblotting (results not shown).

\section{TITRATION OF MONOCLONAL ANTIBODIES}

A titration curve for each MoAb was constructed using the $T$ pallidum ELISA. For MoAbs 15, 21, 29, 30 , and 34 a maximum extinction plateau was maintained at dilutions of up to 1:800, for MoAbs C3E5, D6F7C6, and $1-14 \mathrm{M} 1$ a plateau was maintained at dilutions of up to $1: 3200,1: 1600$, and 1:1600 respectively. At higher dilutions a sharp decline in extinction was noticed. The steepest part of these slopes represented the optimum dilutions for inhibition experiments. The working dilution for each MoAb was therefore chosen where its titration curve started to slope. These titration curves were highly reproducible. Several serum samples from patients with syphilis in the inhibition ELISA using MoAbs at different dilutions to confirm the correct working dilution were tested. No improved inhibition was obtained at other dilutions.

\section{DISCRIMINATION BETWEEN POSITIVE AND} NEGATIVE RESULTS IN THE INHIBITION ELISA

The inhibition of MoAb binding by serum samples from patients with syphilis compared with samples from non-infected people was measured by evaluating the test results in 20 serum samples from patients with untreated syphilis, and 100 control samples. All samples were tested at three different dilutions (1:5, $1: 50$, and $1: 100$ ).

Wide variation in the extinctions of samples with little or no inhibitory capacity made it impossible to correlate the test results to the extinction that was obtained with the labelled MoAb alone. We initially 

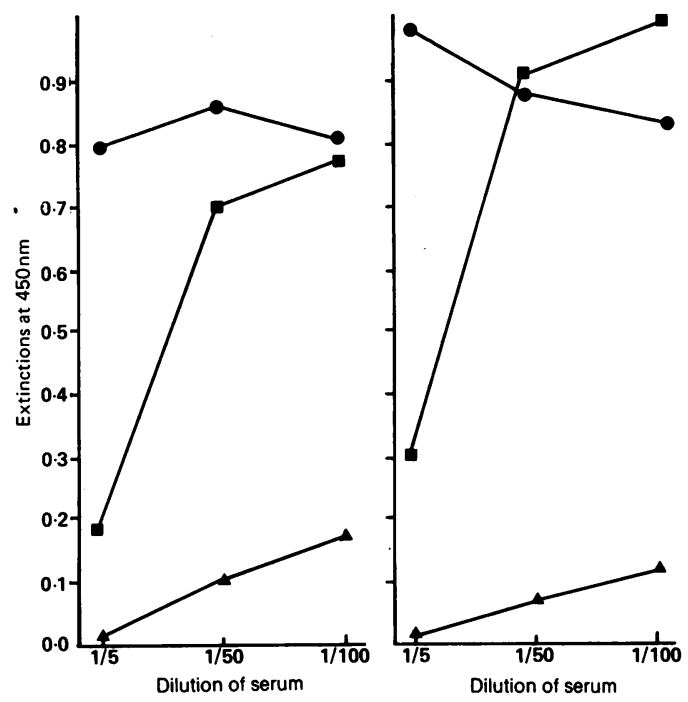

Fig 2 Reactivity (extinction at $450 \mathrm{~nm}$ ) of monoclonal antibodies 1-14M1 (left) and C3E5 (right) in the inhibition ELISA with serum samples that gave ( $\square-\square)$ moderately positive results, ( $\Delta-\Delta)$ strongly positive results, and (-) negative results in serological tests for syphilis.

observed, however, that an increase of extinction of at least 0.5 occurred between the lowest and highest dilution of each serum sample from a patient with syphilis. Such an increase was not observed in any control serum tested. Samples showing an increase of extinction of at least 0.5 , when diluted as stated, were therefore considered to be positive. In further experiments some of the samples from patients with syphilis showed an increase of extinction of less than 0.5 . These samples also showed an extinction of less than 0.3 when diluted at the three different dilutions (fig 2). They were tested again at higher dilutions, when an increase of 0.5 was always observed. Such samples were considered to show strongly positive results in the inhibition ELISA.
INHIBITION OF MOAb BINDING BY SERUM SAMPLES FROM PATIENTS WITH SYPHILIS

All MoAbs were evaluated in the inhibition ELISA.

None of the MoAbs directed against the 34 kilodalton

TmpB were inhibited by serum from patients (results not shown). All MoAbs raised against the 34 kilodalton TmpB were therefore excluded from further investigations. Pronounced inhibition was observed with MoAbs C3E5 and 1-14M1.

Figure 2 shows the results of typical experiments with a serum sample strongly reactive in the inhibition ELISA (from a patient with secondary syphilis, TPHA $2+$, FTA-ABS $3+$, VDRL 1:4), a moderately reactive sample (from a patient with treated syphilis, TPHA $2+$, FTA-ABS $3+$ ), and a non-reactive sample using MoAb 1-14M1 or C3E5 labelled with horseradish peroxidase. The non-reactive serum sample showed high extinctions at all dilutions. When diluted fivefold the moderately reactive sample appreciably inhibited the binding of the labelled conjugate and resulted in low extinctions, but when diluted 100 -fold this sample did not substantially inhibit the binding of labelled MoAb. The strongly reactive serum inhibited the binding of the labelled MoAb to a high extent, and low extinctions were observed for all three dilutions.

\section{SENSITIVITY AND SPECIFICITY OF THE}

INHIBITION ELISA

Table 2 shows the results of testing 58 serum samples from patients with early syphilis and 500 from noninfected people in the inhibition ELISA, TPHA, and FTA-ABS test to assess the sensitivity and specificity of the inhibition ELISA. All 58 samples from patients with untreated early syphilis reacted in at least the FTA-ABS test. More samples from patients with secondary and latent syphilis reacted in the inhibition ELISA using labelled MoAb C3E5 than when MoAb $1-14 \mathrm{M} 1$ was used which resulted in sensitivities of $98 \%$ (mean $100 \%$ for secondary syphilis and $96 \%$ for latent syphilis) with C3E5 and $77 \%$ (mean $83 \%$ for secondary syphilis and $72 \%$ for latent syphilis) with 1-14M1. For primary syphilis, the inhibition ELISA

Table 2 Results of the monoclonal inhibition ELISA with serum samples from patients with syphilis and non-infected people

\begin{tabular}{|c|c|c|c|c|c|c|c|}
\hline \multirow{3}{*}{$\begin{array}{l}\text { Diagnosis } \\
\text { Primary syphilis } \\
\text { Secondary syphilis } \\
\text { Early latent syphilis } \\
\text { Non-infected blood donors }\end{array}$} & \multirow{3}{*}{$\begin{array}{c}\text { No of samples } \\
15 \\
18 \\
25 \\
500\end{array}$} & \multicolumn{3}{|c|}{$\begin{array}{l}\text { Samples giving positive results in: } \\
\text { Inhibition ELISA (figures are numbers and } \\
\text { (percentages) of tests) }\end{array}$} & \multirow{2}{*}{\multicolumn{2}{|c|}{ TPHA }} & \multirow[b]{2}{*}{$F T A-A B S$} \\
\hline & & $\begin{array}{l}M o A b \\
I-I 4 M I\end{array}$ & $\begin{array}{l}\text { MoAb } \\
C 3 E 5\end{array}$ & Both MoAbs & & & \\
\hline & & $\begin{aligned} 13 & (87) \\
15 & (83)^{*} \\
18 & (72) \\
0 & \end{aligned}$ & $\begin{array}{cc}12 & (80) \\
18 & (100) \dagger \\
24 & (96)^{*} \\
0 & \end{array}$ & $\begin{aligned} 14 & (93) \\
18 & (100)^{*} \\
24 & (96) \\
0 & \end{aligned}$ & $\begin{array}{r}14 \\
18 \\
25 \\
1\end{array}$ & $\begin{array}{c}(93) \\
(100) \\
(100) \\
(0 \cdot 2)\end{array}$ & $\begin{array}{rc}15 & (100) \\
18 & (100) \\
25 & (100) \\
2 & (0 \cdot 4)\end{array}$ \\
\hline
\end{tabular}

*Three samples in these groups did not show 0.5 extinction but had $\leqslant 0.3$ extinction.

tOne sample did not show 0.5 extinction increase but had $\leqslant 0.3$ extinction.

For meanings of abbreviated test names see table 1 .

FTA-ABS = fluorescent treponemal antibody absorption test. 
Table 3 Reaction pattern in results of serological tests on serum samples submitted for syphilis serology

\begin{tabular}{|c|c|c|c|c|c|}
\hline \multirow{2}{*}{$\begin{array}{l}\text { TPHA or } \\
F T A-A B S\end{array}$} & \multicolumn{2}{|c|}{ Inhibition ELISA } & \multirow[b]{2}{*}{ No of samples } & \multirow{2}{*}{$\begin{array}{l}\text { Patients with known } \\
\text { treated syphilis }\end{array}$} & \multirow{2}{*}{$\begin{array}{l}\text { People without } \\
\text { evidence of syphilis }\end{array}$} \\
\hline & $1-14 M 1$ & C3E5 & & & \\
\hline $\begin{array}{l}\text { Positive } \\
\text { Positive } \\
\text { Positive } \\
\text { Positive } \\
\text { Negative } \\
\text { Negative } \\
\text { Negative }\end{array}$ & $\begin{array}{l}\text { Positive } \\
\text { Negative } \\
\text { Positive } \\
\text { Negative } \\
\text { Positive } \\
\text { Negative } \\
\text { Negative }\end{array}$ & $\begin{array}{l}\text { Positive } \\
\text { Positive } \\
\text { Negative } \\
\text { Negative } \\
\text { Negative } \\
\text { Positive } \\
\text { Negative }\end{array}$ & $\begin{array}{r}22 \\
17 \\
2 \\
23 \\
5 \\
2 \\
425\end{array}$ & $\begin{array}{r}22 \\
17 \\
2 \\
23\end{array}$ & $\begin{array}{r}5 \\
2 \\
425\end{array}$ \\
\hline
\end{tabular}

See tables 1 and 2 for meanings of abbreviated test names.

using MoAb C3E5 was less sensitive (80\%) than with MoAb 1-14M1 (87\%). In the entire group of untreated patients with early syphilis the sensitivity of the inhibition ELISA using labelled MoAb C3E5 only (93\%) was comparable with that of the TPHA (98\%) and the FTA-ABS test $(100 \%)$. The combined results of both C3E5 and MoAb 1-14M1 inhibition ELISAs (97\%) were also comparable with those of the TPHA and the FTA-ABS test.

The specificity of the inhibition ELISA using either MoAb (C3E5 or 1-14M1) for testing 500 samples from healthy people was $100 \%$, which was comparable with the specificities of the TPHA $(99.8 \%)$ and the FTA-ABS test (99.6\%).

To detect possible cross reactivity of serum samples from patients with other spirochaetoses in the inhibition ELISA, we tested the six samples reactive in the Borrelia burgdorferi immunofluorescence test and the seven samples reactive in the Leptospira icterohaemorrhagiae ELISA. These 13 samples gave negative results in syphilis serology tests (results not shown). The six samples reactive in the Borrelia burgdorferi immunofluorescence test did not react in the inhibition ELISA using labelled MoAbs C3E5 or 1-14M1, but one out of seven samples reactive in the Leptospira ELISA also reacted in the inhibition ELISA using either labelled MoAb.

\section{REACTIVITY OF FRESH SERUM SAMPLES IN THE INHIBITION ELISA}

The 496 samples that were submitted for syphilis serology consisted of 432 from patients without syphilis and 64 from patients treated for syphilis, none of which gave positive results in the VDRL test. These samples were investigated in the inhibition ELISA using labelled MoAb C3E5 or 1-14M1. The results are shown in table 3 . These results were compared with those of the TPHA and the FTA-ABS test. The specificity of the inhibition ELISA in the high risk group of the 432 non-infected patients depends on the MoAb used, and was $98.8 \%$ for $1-14 \mathrm{M} 1$ and $99.5 \%$ for C3E5. After combining the results of both inhibition ELISAs, the specificity was $98.4 \%$. Of the 432 samples not reactive in either treponemal test, five reacted in the inhibition ELISA using labelled MoAb 1-14M1, whereas two other samples gave positive results in the inhibition ELISA when labelled MoAb C3E5 was used. None of the patients who gave positive results in the inhibition ELISA had a history of syphilis.

Of the 64 samples from treated patients, $39(61 \%)$ reacted in the inhibition ELISA using MoAb C3E5, and $24(38 \%)$ when MoAb 1-14M1 was used; 41 $(64 \%)$ reacted positively when the results using both MoAbs were combined. The sensitivity of the inhibition ELISA for diagnosing treated syphilis after combining the test results of the two MoAbs (64\%) was less than the sensitivities of the TPHA $(92 \%)$ and the FTA-ABS (86\%) test.

\section{Discussion}

In the present study an inhibition ELISA for the serodiagnosis of syphilis using antitreponemal MoAbs is reported. Eight MoAbs were investigated for their suitability in the inhibition ELISA. Three MoAbs had been raised against $T$ pallidum organisms and five were raised against the 34 kilodalton recombinant protein, TmpB. All eight MoAbs were reactive in the $T$ pallidum ELISA, which indicated that the $T$ pallidum antigens used in the inhibition ELISA contained the epitopes to which the MoAbs were reactive. Furthermore, the MoAbs reacted in the TPHA and the FTA test with the exception of MoAb 1-14M1 in the FTA test. Although MoAb 1-14M1 was raised against the 42 kilodalton protein TmpA, which is associated with treponemal membrane, ${ }^{24}$ it did not react with presumed exposed treponemal surface antigens in the FTA test. As MoAbs directed to the 34 kilodalton TmpB were not inhibited by serum from patients with syphilis, they were not suitable for use in the inhibition ELISA. Homologous inhibition of labelled MoAb by its unlabelled counterpart was shown for all MoAbs except MoAb D6F7C6, which indicated that the labelling of D6F7C6 may have altered the structure of its antigen binding sites.

Regarding its specificity in people assumed to be healthy, the inhibition ELISA using MoAbs C3E5 and 
1-14M1 was comparable with the specificities of the TPHA and the FTA-ABS test. In the 432 serum samples from patients attending the STD clinic, the specificity of the inhibition ELISA was lower. This may have been because incomplete disease histories were obtained from these patients, who were at high risk for acquiring STDs.

In patients with untreated syphilis the sensitivities of the inhibition ELISA were $79 \%$ using MoAb 1-14M1, 93\% using C3E5, and $97 \%$ using both. The sensitivity of the inhibition ELISA using both MoAbs was therefore comparable with those of the TPHA and the FTA-ABS test. The use of MoAb C3E5 alone provided a test with $93 \%$ sensitivity. This, in combination with the test results obtained with MoAb 1-14M1, slightly enhanced the sensitivity for patients with primary syphilis, but should be confirmed by testing more serum samples.

The ideal inhibition assay takes advantage of a MoAb that is able to react at all stages of syphilis. Such a MoAb was not found in this study. Several possible explanations exist for the differences in reactivity between the MoAbs in the inhibition ELISA. The avidity of the MoAb may be higher than that of the polyclonal serum directed to the common determinant, which results in less inhibition. Serum antibodies reactive to the common determinant may be present in small amounts. Serum antibodies directed to the appropriate determinant may not be present, depending on the stage of syphilis.

The epitope to which the MoAb was reactive may possibly not be presented to the host immune system during natural infection. This possibility may apply to the MoAbs raised against the recombinant protein TmpB. The use of these MoAbs in the inhibition ELISA indicated that they could not be inhibited by serum from patients with syphilis. This could have been due to an antibody response of mice to epitopes of the recombinant treponemal protein, TmpB, that differed from the epitopes of the naturally occurring TmpB from treponemes. In a direct ELISA using TmpB as antigen, reactions were seen in only a limited number of serum samples from patients with untreated syphilis that gave positive results in other tests for syphilis, which indicated that certain patients do not produce antibodies to the 34 kilodalton protein TmpB (Schouls et al, submitted for publication). This confirms the poor antibody response to TmpB in man.

The use of more than one MoAb in the inhibition ELISA may overcome the disadvantages of using a single MoAb. As can be expected from this theoretical viewpoint, however, the specificity of the test would decline for each additional MoAb that is used. This was shown by combining the results of the inhibition ELISA using MoAbs C3E5 and 1-14M1 to screen a high risk population. In 64 serum samples from patients with treated syphilis that were not reactive in the VDRL but were reactive in at least one treponemal test, the sensitivity of the inhibition ELISA using MoAb 1-14M1 was appreciably less than the sensitivity using MoAb C3E5.

The fact that MoAb 1-14M1 was less effective in diagnosing treated syphilis than MoAb C3E5 agrees with the observation that the serum antibodies reactive to the 42 kilodalton TmpA derived from recombinant DNA showed a rapid decline in reactivity soon after the patients were treated. ${ }^{28}$

Technically, non-reactive serum samples showed high variation of extinction in the inhibition ELISA. This was circumvented by testing each serum sample at three different dilutions. The dilutions that were chosen were based on the limited number of samples tested. An improvement in future experiments may be the inclusion of dilutions higher than 1:100 of each serum specimen.

The application of MoAbs in an inhibition assay offers the opportunity to show antibody response to distinct epitopes. Although there is a considerable similarity between the antigenic structures of pathogenic treponemes, epitopes of different pathogenic treponemal species may differ. In future, monoclonal antibodies directed to such epitopes may provide an inhibition ELISA to differentiate between various pathogenic treponemes.

In conclusion, the inhibition ELISA using the combination of test results of two MoAbs directed to 42 and 47 kilodalton treponemal proteins may be a highly specific and sensitive test for diagnosing early untreated syphilis. Because of its high specificity, the inhibition ELISA may have potential for confirming early untreated syphilis. Furthermore, the inhibition ELISA forms a model for the study of a wider panel of monoclonal antibodies whose inhibition pattern may possibly give guidance to the stage of syphilis and treatment status.

We thank $R$ van Zelst and $E$ van der Brugge for their technical contributions to this study, L Schouls for preparing the TmpB antigen, and $G$ Aelbers and $C$ Agterberg for preparing and purifying the MoAbs.

\section{References}

1 Rathlev T. Haemagglutination test utilizing pathogenic Treponema pallidum for the serodiagnosis of syphilis. British Journal of Venereal Diseases 1967;43:181-5.

2 Hunter EF, Deacon WE, Meyer PE. An improved FTA test for syphilis, the absorption procedure (FTA-ABS). Public Health Rep 1964;79:410-2.

3 IJsselmuiden OE, Meinardi MMHM, van der Sluis JJ, Menke HE, Stolz E, van Eijk RVW. Enzyme-linked immunofiltration assay for rapid serodiagnosis of syphilis. Eur J Clin Microbiol 
1987;6:281-5.

4 Strandberg Pedersen N, Sand Petersen C, Vejtorp M, Axelsen NH. Serodiagnosis of syphilis by an enzyme-linked immunosorbent assay for IgG antibodies against the Reiter treponeme flagellum. Scand J Immunol 1982;15:341-8.

5 Radolf JD, Lernhardt EB, Fehninger TE, Lovett MA. Serodiagnosis of syphilis by enzyme linked immunosorbent assay with purified recombinant Treponema pallidum antigen 4D. J Infect Dis 1986;153:1023-7.

6 Rodgers GC, Laird WJ, Coates SR, Mack DH, Huston M, Sminsky JJ. Serological characterization and gene localization of an Escherichia coli-expressed 37-kilodalton Treponema pallidum antigen. Infect Immun 1986;53:16-25.

7 Hensel U, Wellensiek H, Bhakdi S. Sodium dodecyl sulfatepolyacrylamide gel elctrophoresis immunoblotting as a serological tool in the diagnosis of syphilitic infections. $J$ Clin Microbiol 1985;21:82-7.

8 Robertson SM, Kettman JR, Miller JN, Norgard MV. Murine monoclonal antibodies specific for virulent Treponema pallidum (Nichols). Infect Immun 1982;36:1076-85.

9 Marchitto KS, Jones SA, Schell RF, Holmans PL, Norgard MV. Monoclonal antibody analysis of specific antigenic similarities among pathogenic Treponema pallidum subspecies. Infect Imimun 1984;45:660-6.

10 Saunders JM, Folds JD. Development of monoclonal antibodies that recognize Treponema pallidum. Infect Immun 1983;41: $844-7$.

11 van Embden JD, van der Donk HJ, van Eijk RVW, et al. Molecular cloning and expression of Treponema pallidum DNA in Escherichia coli K-12. Infect Immun 1983;42:187-96.

12 Thornburg RW, Morrison-Plummer J, Baseman JB. Monoclonal antibodies to Treponema pallidum: recognition of a major polypeptide antigen. Genitourin Med 1985;61:1-6.

13 Lukehart SA, Tam MR, Hom J, Baker-Zander SA, Holmes KK, Nowinski RC. Characterization of monoclonal antibodies to Treponema pallidum. J Immunol 1985;134:585-92.

14 Moskophidis M, Müller F. Monoclonal antibodies to immunodominant surface-exposed protein antigens of Treponema pallidum. Eur J Clin Microbiol 1985;4:473-7.

15 Baker-Zander SA, Lukehart SA. Molecular basis of immunological cross-reactivity between Treponema pallidum and Treponema pertenue. Infect Immun 1983;42:634-8.

16 Maio R, Fieldsteel AH. Genetic relationship between Treponema pallidum and Treponema pertenue, two non-cultivable human pathogens. J Bacteriol 1980;141:427-9.
17 Miller JH, De Bruijn JH, Bekker JH, Onvlee PC. The antigenic structure of Treponema pallidum, Nichols strain. I. The demonstration, nature and localization of specific and shared antigens. J Immunol 1966;96:450-6.

18 Baseman JB, Nichols JC, Rumpp JW, Hayes NS. Purification of Treponema pallidum from infected rabbit tissue: resolution into two treponemal populations. Infect Immun 1974;10:1062-7.

19 De Bruijn JH. A simplified method for the preparation of Reiter protein antigen. Antonie van Leeuwenhoek 1960;26:317-20.

20 US Public Health Service. Manual of tests for syphilis. Washington DC: US Department of Health, Education and Welfare, US Government Printing Office, 1969 (PHS Publication No 411): 1-77.

21 Russell H, Sampson JS, Schmidt GP, Wilkinson HQ, Plikaytis B. Enzyme-linked immunosorbent assay and indirect immunofluorescence assay for Lyme disease. J Infect Dis 1984;149: 465-70.

22 Terpstra WJ, Ligthart GS, Schoone GJ. Serodiagnosis of human leptospirosis by enzyme-linked immunosorbent assay (ELISA). Zentralbl Bakteriol [A] 1980;247:400-5.

23 van Eijk RVW, Menke HE, Tideman GJ, Stolz E. Enzyme linked immunosorbent assays with Treponema pallidum or axial filament of $T$ phagedenis biotype Reiter as antigen: evaluation as screening tests for syphilis. Genitourin Med 1986;62:367-72.

24 Hansen EB, Pedersen PE, Schouls LM, Severin E, van Embden JDA. Genetic characterization and partial sequence determination of a Treponema pallidum operon expressing two immunogenic membrane proteins in Escherichia coli. J Bacteriol 1985; 162:1227-37.

25 Nakane PK, Kawaoi A. Peroxidase-labeled antibody. A new method of conjugation. J Histochem Cytochem 1974;22: 1084-91.

26 Laemmli UK. Cleavage of structural proteins during the assembly of the head of bacteriophage T4. Nature 1970;227:680-5.

27 Burnette WN. "Western blotting": electrophoretic transfer of proteins from sodium dodecyl sulfate-polyacrylamide gels to unmodified nitrocellulose and radiographic detection with antibody and radioiodinated protein A. Anal Biochem 1981; 112:195-203.

28 IJsselmuiden OE, Schouls LM, Stolz E, et al. Sensitivity and specificity of an enzyme-linked immunosorbent assay using the recombinant DNA-derived Treponema pallidum protein TmpA for serodiagnosis of syphilis and the potential use of TmpA for assessing the effect of antibiotic therapy. J Clin Microbiol 1989; 27:152-7. 